\title{
Color reduction of raw sugar syrup using hydrogen peroxide
}

\section{Redução de cor em xarope de açúcar bruto usando peróxido de hidrogênio}

\author{
Juliana Lorenz Mandro Campiol ${ }^{1 *}$ (D), Nathália Torres Correa Magri', \\ Juliana Aparecida de Souza Sartori ${ }^{1}$, Felipe Iwagaki Braga Ogando', \\ Claudio Lima de Aguiar ${ }^{1}$
}

${ }^{1}$ Universidade de Sao Paulo (USP), Escola superior de agricultura "Luiz de Queiroz", Departamento de Agroindústria, Alimentos e Nutrição, Laboratório Hugot de Tecnologia em Sucroderivados, Piracicaba/SP - Brasil

*Corresponding Author: Juliana Lorenz Mandro Campiol, Universidade de Sao Paulo (USP), Escola superior de agricultura "Luiz de Queiroz", Departamento de Agroindústria, Alimentos e Nutrição, Laboratório Hugot de Tecnologia em Sucroderivados, Avenida Pádua Dias, 11, CEP: 13418-900, Piracicaba/SP - Brasil, e-mail: julianalorenz.m@usp.br

Cite as: Campiol, J. L. M., Magri, N. T. C., Sartori, J. A. S., Ogando, F. I. B., \& Aguiar, C. L. (2019). Color reduction of raw sugar syrup using hydrogen peroxide. Brazilian Journal of Food Technology, 22, e2018072.

https://doi.org/10.1590/1981-6723.07218

\begin{abstract}
A commercial $\mathrm{H}_{2} \mathrm{O}_{2}$ solution $(35 \%, \mathrm{v} / \mathrm{v}$ ) was evaluated as a clarifying agent for raw, type VHP (very high polarization) sugar syrup, using an experimental design applying artificial neural networks (ANN). Fifteen experimental runs were carried out and the samples were taken at the following time intervals: $0,5,10,15,20,25,30,40,50,60$, 75 and $90 \mathrm{~min}$. The treatments were carried out using an experimental design consisting of three variables: $\mathrm{H}_{2} \mathrm{O}_{2}$ (X1: 0; 202.4; 500; 797.6 and $\left.1.000 \mathrm{mg} \mathrm{L}^{-1}\right) ; \mathrm{pH}(\mathrm{X} 2: 3.32,5,7.5,10$ and 11.68) and temperature (X3: 16.4, 30, 50, 70 and $83.6^{\circ} \mathrm{C}$ ). The theoretical and measured values fitted the analysis by artificial neural networks (ANN) well. A reduction in colour (ICUMSA method) was observed between 60 and $75 \mathrm{~min}$, except for treatments \# 11 $\left(\mathrm{pH}=11.68 ; 50^{\circ} \mathrm{C}\right.$ and $\left.500 \mathrm{mgH}_{202} \mathrm{~L}^{-1}\right), \# 13\left(\mathrm{pH}=7.5 ; 83.6^{\circ} \mathrm{C}\right.$ and $\left.500 \mathrm{mgH}^{202} \mathrm{~L}^{-1}\right)$ and $\# 15\left(\mathrm{pH}=7.5 ; 50^{\circ} \mathrm{C}\right.$ and $1.000 \mathrm{mg} \mathrm{H}^{202} \mathrm{~L}^{-1}$ ), which showed a colour reduction after $30 \mathrm{~min}$. In the treatments at $\mathrm{pH} 3.32$ or 11.68 , temperature of $83.6^{\circ} \mathrm{C}$ and $\mathrm{H}_{2} \mathrm{O}_{2}$ dose of $1.000 \mathrm{mg} \mathrm{L}^{-1}$, an average sucrose degradation of $55 \%$ was observed. The best colour reduction result was obtained with treatment $\# 9\left(\mathrm{pH} \mathrm{7.5,50}{ }^{\circ} \mathrm{C}\right.$ and $\left.500 \mathrm{mg} \mathrm{H} \mathrm{OO} \mathrm{L}^{-1}\right)$, although sucrose degradation of $26 \%$ was observed.
\end{abstract}

Keywords: Clarification; Oxidation; Sucrose; Reduction; Kinetics; Degradation.

\section{Resumo}

Uma solução comercial de $\mathrm{H}_{2} \mathrm{O}_{2}(35 \%$, v/v) foi avaliada como agente clarificante em xarope de açúcar tipo VHP (alta polarização), em arranjo experimental de redes neurais artificiais (RNA). Quinze corridas experimentais foram conduzidas e as amostras foram coletadas em intervalos de tempo de $0,5,10,15,20,25,30,40,50,60$, 75 e 90 min. Os ensaios foram conduzidos usando um arranjo experimental composto por três variáveis, sendo: $\mathrm{H}_{2} \mathrm{O}_{2}$ (X1: $0 ; 202,4 ; 500 ; 797,6$ e $\left.1.000 \mathrm{mg} \mathrm{L}^{-1}\right) ; \mathrm{pH}\left(\mathrm{X} 2: 3,32 ; 5 ; 7,5 ; 10\right.$ e 11,68), e temperatura (X3: 16,4; 30; 50; 70 e 83,6 $6^{\circ} \mathrm{C}$ ). Os valores teóricos e mensurados se encaixam bem na análise por RNA. Observou-se redução da coloração entre 
60 e 75 min, com exceção dos tratamentos \#11 ( pH=11,68; $50^{\circ} \mathrm{C}$ e $\left.500 \mathrm{mgh}_{2} \mathrm{O} \mathrm{L}^{-1}\right)$, \#13 $\left(\mathrm{pH}=7,5 ; 83,6^{\circ} \mathrm{C}\right.$ e $\left.500 \mathrm{mgh}_{2 \mathrm{O} 2} \mathrm{~L}^{-1}\right)$ e \#15 ( $\mathrm{pH}=7,5 ; 50^{\circ} \mathrm{C}$ e $\left.1.000 \mathrm{mgH}_{202} \mathrm{~L}^{-1}\right)$, que apresentaram redução de cor após 30 min. No tratamento com $\mathrm{pH} 3,32$ ou 11,68 , temperatura $83,6^{\circ} \mathrm{C}$ e dose de $\mathrm{H}_{2} \mathrm{O}_{2}$ de $1.000 \mathrm{mg} \mathrm{L}^{-1}$, observou-se uma degradação da sacarose de 55\%, em média. No tratamento \# $9\left(\mathrm{pH} 7,5,50^{\circ} \mathrm{C}\right.$ e $\left.500 \mathrm{mg}_{\mathrm{H} 2 \mathrm{O}} \mathrm{L}^{-1}\right)$, obteve-se o melhor resultado para a redução de cor, embora tenha sido percebida $26 \%$ de degradação de sacarose.

Palavras-chave: Clarificação; Oxidação; Sacarose; Redução; Cinética; Degradação.

\section{Introduction}

Hydrogen peroxide $\left(\mathrm{H}_{2} \mathrm{O}_{2}\right)$ has a standard reduction potential $\left(\mathrm{E}^{0}\right)$ of $1.77 \mathrm{~V}$, higher than that of other oxidants such as chlorine $\left(\mathrm{E}^{0}=1.36 \mathrm{v}\right)$, chlorine dioxide $\left(\mathrm{E}^{0}=1.50 \mathrm{v}\right)$, molecular oxygen $\left(\mathrm{E}^{0}=1.23 \mathrm{v}\right)$ and potassium permanganate $(\mathrm{E}=1.67 \mathrm{v})$. In a reaction medium, $\mathrm{H}_{2} \mathrm{O}_{2}$ can be converted to hydroxyl radicals $(\bullet \mathrm{OH})$, a highly reactive species $\left(\mathrm{E}^{0}=2.80 \mathrm{~V}\right)$ (Üzer et al., 2017; Mattos et al., 2013), making it of interest in the treatment of drinking water and industrial effluents (Guo et al., 2017; Russo et al., 2017; Spasiano et al., 2016). Stout et al. (2017), Jervis et al. (2015) and Fairbanks (2009) reported that hydrogen peroxide has been used in the bleaching of different types of food. Since $1979, \mathrm{H}_{2} \mathrm{O}_{2}$ has been recognized as a GRAS (Generally Recognized as Safe) product by the Food and Drug Administration (FDA, 2015).

Studies on the use of $\mathrm{H}_{2} \mathrm{O}_{2}$ in sugarcane juice or sugar beet clarification have been carried out (Mane et al., 2000; Sartori et al., 2015a; Sartori et al., 2015b; Mandro et al., 2015), and the action ${ }^{2} \mathrm{H}_{2} \mathrm{O}_{2}$ on compounds such as melanoids, melanins, caramels, polyphenols, starch and amino acids, which are present during the processes used to obtain sugar, reported. $\mathrm{H}_{2} \mathrm{O}_{2}$ can also act during the purification/clarification step of Very High Polarization (VHP) or Very Very High Polarization (VVHP) raw sugar syrup during sugar refining (Mandro et al., 2017). Nowadays, the sugar refining process consists of the dissolution of crystal sugar in hot water, and its passage through ion exchange resins and activated carbon to remove the impurities (Crema, 2012). The high costs are related to the regeneration pof the resins, due to a progressive loss of ion exchange capacity (Rodrigues, 1998; Baccar et al., 2009).

Thus, by way of an analysis in artificial neural networks, this study aimed to evaluate the clarification of sugar syrup (VHP type) using $\mathrm{H}_{2} \mathrm{O}_{2}$ as the clarification agent.

\section{Material and methods}

\subsection{Sugar and reagents}

VHP type crystal sugar (Very High Polarization) was obtained in Piracicaba - SP, Brazil. The sugar samples were characterized, and the values obtained are presented below: $\mathrm{pH}=6.56$ (in aqueous solution at $60^{\circ}$ Brix), humidity $=0.026 \%$, polarization (or sucrose content by polarimetry) $=97.21^{\circ} \mathrm{Z}$, ash $=0.66 \%$ and ICUMSA colour $=417.58 \mathrm{IU}$. Hydrogen peroxide $($ commercial solution at $35 \%(\mathrm{w} / \mathrm{w}))$; Catalase $($ freezedriedpowder, 2000-5000 units/mg protein; Sigma-Aldrich); HCl $0.1 \mathrm{~mol} \mathrm{~L}^{-1}$; $\mathrm{NaOH} 0.1 \mathrm{~mol} \mathrm{~L}^{-1}$; sucrose ( $\geq 99.5 \%$; Sigma-Aldrich) and acetonitrile (Tedia Co., HPLC grade).

\subsection{Sugar syrup preparation}

The sugar syrup was prepared by dilution in ultrapure water $(18 \mathrm{M} \Omega \mathrm{cm})$ up to a final concentration of 66 Brix (\% soluble solids). Each treatment used $400 \mathrm{~mL}$ of 66 Brix syrup, whose concentration was measured in a refractometer Mod. RFM-712 (Bellingham+Stanley Co., UK). 


\subsection{Treatment with hydrogen peroxide}

The conical flasks $(500 \mathrm{~mL})$ were maintained under different reaction conditions depending on the experimental design: temperature $\left(16.4\right.$ to $\left.83.6{ }^{\circ} \mathrm{C}\right) ; \mathrm{pH}(3.32$ to 11.68$)$ and $\mathrm{H}_{2} \mathrm{O}_{2}$ doses (between 0 and $1000 \mathrm{mg} \mathrm{L}^{-1}$ ) (Table 1). Each experimental run was monitored for $90 \mathrm{~min}$, and samples were collected at the following time intervals $0,5,10,15,20,25,30,40,50,60,75$ and $90 \mathrm{~min}$. Colour reduction was analysed by the ICUMSA method and the sucrose contents by HPLC. The results were expressed as the average \pm standard deviation of three analytical replicates. Bovine liver catalase (freeze-driedpowder, $2000-5000 \mathrm{U} / \mathrm{mg}$ protein; Sigma-Aldrich) was added at the end of each treatment to disrupt the oxidation reactions of the hydrogen peroxide.

Table 1. Initial conditions of the 15 treatments used in the peroxidation treatments.

\begin{tabular}{ccccc}
\hline Runs \# & Initial ${ }^{\circ} \mathbf{B r i x}$ & Initial $\mathbf{~ H H}$ & $\begin{array}{c}\text { Initial temperature } \\
\left({ }^{\circ} \mathbf{C}\right)\end{array}$ & $\mathbf{H}_{2} \mathbf{O}_{2}(\mathbf{m g} \mathbf{~ m L}-\mathbf{1})$ \\
\hline $\mathbf{1}$ & 62.6 & 5.0 & 30 & 202.4 \\
$\mathbf{2}$ & 62.6 & 10.0 & 30 & 202.4 \\
$\mathbf{3}$ & 62.6 & 5.0 & 70 & 202.4 \\
$\mathbf{4}$ & 62.6 & 10.0 & 70 & 202.4 \\
$\mathbf{5}$ & 62.6 & 5.0 & 30 & 797.6 \\
$\mathbf{6}$ & 62.6 & 10.0 & 30 & 797.6 \\
$\mathbf{7}$ & 65.5 & 5.0 & 70 & 797.6 \\
$\mathbf{8}$ & 65.5 & 10.0 & 70 & 797.6 \\
$\mathbf{9}$ & 66.2 & 7.5 & 50 & 500 \\
$\mathbf{1 0}$ & 66.2 & 3.32 & 50 & 500 \\
$\mathbf{1 1}$ & 66.2 & 11.68 & 50 & 500 \\
$\mathbf{1 2}$ & 66.2 & 7.5 & 16.4 & 500 \\
$\mathbf{1 3}$ & 66.2 & 7.5 & 83.6 & 500 \\
$\mathbf{1 4}$ & 66.2 & 7.5 & 50 & 0 \\
\hline $\mathbf{1 5}$ & 66.2 & 7.5 & 50 & 1.000 \\
\hline
\end{tabular}

\subsection{ICUMSA colour analysis of the sugar syrups}

The colour analyses of the samples treated with hydrogen peroxide were carried out using method GS1/37 (International Commission for Uniform Methods of Sugar Analysis, 2011). Initially, the sample Brix was adjusted to 30 Brix using a bench refractometer and they were then vacuum filtered through a PTFE $0.45 \mu \mathrm{m}$ $\phi$ pore membrane (Millipore Co., Brazil). The $\mathrm{pH}$ was then adjusted to $7 \pm 0.05$ with $\mathrm{HCl} 0.1 \mathrm{~mol} \mathrm{~L}^{-1}$ or $\mathrm{NaOH}$ $0.1 \mathrm{~mol} \mathrm{~L}^{-1}$ and the absorbance measured in a UV-Mini 1240 spectrophotometer (Shimadzu Co., Japan) at $420 \mathrm{~nm}$. The ICUMSA colour of the samples was expressed as the result obtained from the Expression (1):

ICUMSA colour $(420 \mathrm{~nm})=\frac{\mathrm{ABS}}{(\mathrm{b} \mathrm{c})} \times 1000$

Where: ABS: absorbance at $420(\mathrm{~nm})$; b: Cell optical path $(\mathrm{cm})$; c: Sucrose concentration $\left(\mathrm{g} \mathrm{mL}^{-1}\right)$ in solution in Brix at $20^{\circ} \mathrm{C}$. 


\subsection{HPLC-ELSD analysis of sucrose contents}

Sucrose was determined by HPLC equipped with a low temperature evaporative light scattering detector (ELSD-LT). The mobile phase consisted of acetonitrile and water $(85: 15, \mathrm{v} / \mathrm{v})$ previously filtered through a $0.45 \mu \mathrm{m}$ pore diameter PTFE membrane. The samples were passed through a Kromasil $100 \mathrm{NH}_{2}-50$ $(250 \mathrm{~mm} \times 46 \mathrm{~mm}, 5 \mu \mathrm{m})$ column, maintained at $30^{\circ} \mathrm{C}$, under the following analytical conditions: flow rate of $1.0 \mathrm{~mL} \mathrm{~min}{ }^{-1}$, detector temperature of $35{ }^{\circ} \mathrm{C}$ and nitrogen as the nebulizer gas at a pressure of $350 \mathrm{kPa}$. The sucrose concentrations (injection volume $=5 \mu \mathrm{L}$ ) were determined in triplicate by comparison with a calibration curve for sucrose of from 0.1 to $0.5 \mathrm{~g} \mathrm{~L}^{-1}$ (Sigma-Aldrich, HPLC grade).

\subsection{Data analysis of the sugar syrup treated by hydrogen peroxide}

An artificial neural network (ANN) was structured for the empirical prediction of the results. In the input layer, the values added were divided between the dependent (ICUMSA colour responses and sucrose contents of the sugar syrup samples) and controllable independent values (temperature $\left({ }^{\circ} \mathrm{C}\right) ; \mathrm{pH}$; hydrogen peroxide doses ( $\left.\mathrm{mg} \mathrm{mL}^{-1}\right)$ and Brix). The validation test of the networks was carried out using 4 to 10 neurons. The software used for data preparation, adjustment and simulation of the neural networks was developed at CESQ/DEQ-EPUSP (Nascimento et al., 2000) and the relative importance of the variables was assessed using the Holdback Input Randomization Method (HIPR) proposed by Kemp et al. (2007). This method is based on a comparison of the errors caused in each output of the model by random disturbances imposed on each of the input variables.

\section{Results and discussion}

The reductions of the ICUMSA colour and sucrose contents of the sugar syrup samples were analysed with an ideal number of neurons for each treatment by way of the Learning-set (LS) and Test-set (TS). The values obtained for the angles and determination coefficients of the Learning-set (LS) and Test-set (TS) from 4 to 10 neurons can be seen in Figures 1a and 1b, respectively. For the ICUMSA colour and sucrose, the value closest to 1 for the Learning-set (LS) and Test-set (TS) coefficients was 8 neurons. Thereby, a representation of 8 neurons was chosen for a better fit of the artificial neural networks (ANN). 

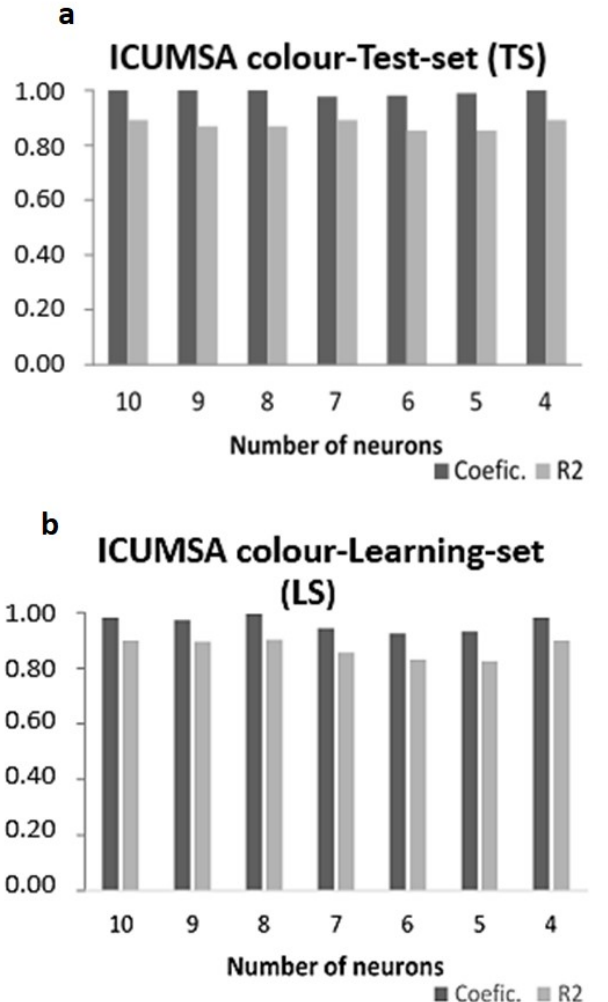

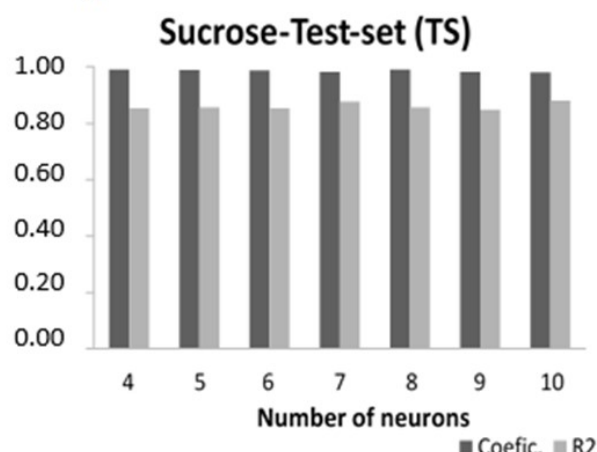

- Coefic. $=\mathrm{R} 2$

b Sucrose-Learning-set (LS)

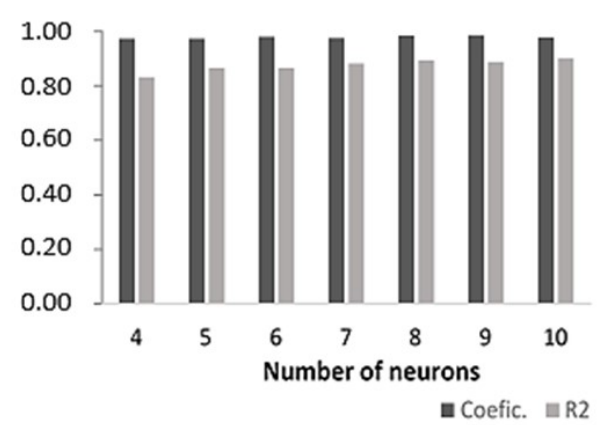

Figure 1. Variation of the angular and determination (R2) coefficients for the ICUMSA colour and sucrose according to the number of neurons in the hidden layer $(\mathrm{NH})$. Number of presentations $=20.000$. (a) LS data; (b) TS data.

The simulated values were similar to those obtained in the experiment. The artificial neural networks obtained good adjustment and were able to predict the results of the ICUMSA colour (Figure 2). Treatments $\# 9\left(\mathrm{pH}=7.5 ; 50{ }^{\circ} \mathrm{C}\right.$ and $\left.500 \mathrm{mg}_{\mathrm{H} 2 \mathrm{O} 2} \mathrm{~L}^{-1}\right)$ and $\# 12\left(\mathrm{pH}=7.5 ; 16.4{ }^{\circ} \mathrm{C}\right.$ and $\left.500 \mathrm{mg}_{\mathrm{H} 2 \mathrm{O} 2} \mathrm{~L}^{-1}\right)$ presented greater similarity between the real and simulated values (Figure 2). Treatment \#9 showed a greater reduction in ICUMSA colour ( $82 \%$ reduction) (Table 2), reaching its peak between 60 and $75 \mathrm{~min}$. On the other hand, treatment $\# 14\left(\mathrm{pH}=7.5 ; 50{ }^{\circ} \mathrm{C} ; 0 \mathrm{mg}_{\mathrm{H} 2 \mathrm{O} 2} \mathrm{~L}^{-1}\right)$ showed the lowest reduction in ICUMSA colour, obviously due to the absence of the clarifying agent. 
Table 2. Experimental test conditions with variations in $\mathrm{pH}$, temperature and hydrogen peroxide and the concentrations of ICUMSA colour (IU) and sucrose (mg $\left.\mathrm{L}^{-1}\right)$ at 30 min intervals.

\begin{tabular}{|c|c|c|c|c|c|c|c|c|c|c|c|c|}
\hline Runs \# & Brix & Initial pH & $\begin{array}{c}\text { Initial } \\
\text { temperature }{ }^{\circ} \mathrm{C} \\
\end{array}$ & $\mathrm{H}_{2} \mathrm{O}_{2} \mathrm{mg} \mathrm{L}^{-1}$ & $\begin{array}{l}\text { to }=0 * \\
\text { Colour }\end{array}$ & $\begin{array}{l}11=30^{*} \\
\text { Sucrose }\end{array}$ & $\begin{array}{l}t 2=60^{*} \\
\text { Colour }\end{array}$ & $\begin{array}{l}\text { t3 }=90^{*} \\
\text { Sucrose } \\
\end{array}$ & Colour & Sucrose & Colour & Sucrose \\
\hline 1 & 62.6 & 5.0 & 30 & 202.4 & 408.5 & 520.2 & 308.1 & 507.7 & 325.0 & 535.1 & 325.7 & 545.8 \\
\hline 2 & 62.6 & 10.0 & 30 & 202.4 & 511.3 & 578.5 & 288.4 & 515.4 & 331.5 & 524.3 & 264.7 & 540.3 \\
\hline 3 & 62.6 & 5.0 & 70 & 202.4 & 425.0 & 750.7 & 320.1 & 616.9 & 324.7 & 543.9 & 262.5 & 618.2 \\
\hline 4 & 62.6 & 10.0 & 70 & 202.4 & 435.1 & 534.7 & 251.1 & 543.8 & 87.0 & 667.4 & 95.5 & 588.9 \\
\hline 5 & 62.6 & 5.0 & 30 & 797.6 & 412.7 & 769.7 & 234.9 & 470.4 & 101.6 & 548.5 & 171.6 & 537.2 \\
\hline 6 & 62.6 & 10.0 & 30 & 797.6 & 465.0 & 877.9 & 335.6 & 579.0 & 291.1 & 437.4 & 193.9 & 525.3 \\
\hline 7 & 65.5 & 5.0 & 70 & 797.6 & 500.2 & 631.2 & 288.9 & 354.5 & 259.2 & 438.1 & 264.3 & 350.6 \\
\hline 8 & 65.5 & 10.0 & 70 & 797.6 & 434.9 & 645.2 & 236.9 & 339.3 & 178.4 & 351.9 & 225.0 & 381.8 \\
\hline 9 & 66.2 & 7.5 & 50 & 500 & 850.4 & 341.6 & 256.0 & 290.6 & 207.7 & 223.3 & 157.3 & 229.2 \\
\hline 10 & 66.2 & 3.32 & 50 & 500 & 477.8 & 597.1 & 277.2 & 214.7 & 166.8 & 224.7 & 309.0 & 219.1 \\
\hline 11 & 66.2 & 11.68 & 50 & 500 & 464.2 & 830.3 & 155.9 & 516.7 & 267.9 & 354.6 & 290.5 & 382.4 \\
\hline 12 & 66.2 & 7.5 & 16.4 & 500 & 941.5 & 418.9 & 484.2 & 221.7 & 539.4 & 189.4 & 516.9 & 219.5 \\
\hline 13 & 66.2 & 7.5 & 83.6 & 500 & 526.5 & 431.1 & 183.9 & 284.1 & 48.1 & 247.9 & 124.5 & 237.3 \\
\hline 14 & 66.2 & 7.5 & 50 & 0 & 444.6 & 362.0 & 447.3 & 333.6 & 452.9 & 540.7 & 425.7 & 378.4 \\
\hline 15 & 66.2 & 7.5 & 50 & 1000 & 454.6 & 335.7 & 228.9 & 187.8 & 221.7 & 156.9 & 194.3 & 157.5 \\
\hline
\end{tabular}

* Real values obtained after clarification treatments with hydrogen peroxide. 
Treatments $\# 11\left(\mathrm{pH}=11.68 ; 50^{\circ} \mathrm{C}\right.$ and $\left.500 \mathrm{mg}_{\mathrm{H} 2 \mathrm{O} 2} \mathrm{~L}^{-1}\right), \# 13\left(\mathrm{pH}=7.5 ; 83.6{ }^{\circ} \mathrm{C}\right.$ and $\left.500 \mathrm{mg}_{\mathrm{H} 2 \mathrm{O} 2} \mathrm{~L}^{-1}\right)$ and $\# 15\left(\mathrm{pH}=7.5 ; 50^{\circ} \mathrm{C}\right.$ and $\left.1.000 \mathrm{mg}_{\mathrm{H} 2 \mathrm{O} 2} \mathrm{~L}^{-1}\right)$ showed greater reductions in ICUMSA colour up to $30 \mathrm{~min}$.

According to Lange et al. (2006), the $\mathrm{pH}$ of the reaction is important for $\mathrm{H}_{2} \mathrm{O}_{2}$ stability, because the speed and efficiency of oxidation are affected since $\mathrm{H}_{2} \mathrm{O}_{2}$ rapidly decomposes producing oxygen and water in alkaline $\mathrm{pH}$ values.

When $\mathrm{H}_{2} \mathrm{O}_{2}$ is in excess, it captures the $\mathrm{OH}^{\bullet}$ radicals $\left(\mathrm{H}_{2} \mathrm{O}_{2}+\mathrm{OH} \rightarrow \mathrm{OH}^{\bullet}{ }_{2}+\mathrm{H}_{2} \mathrm{O}\right)$, which reduces oxidation efficiency (Araujo et al., 2006; Teran, 2014).

Treatment 9

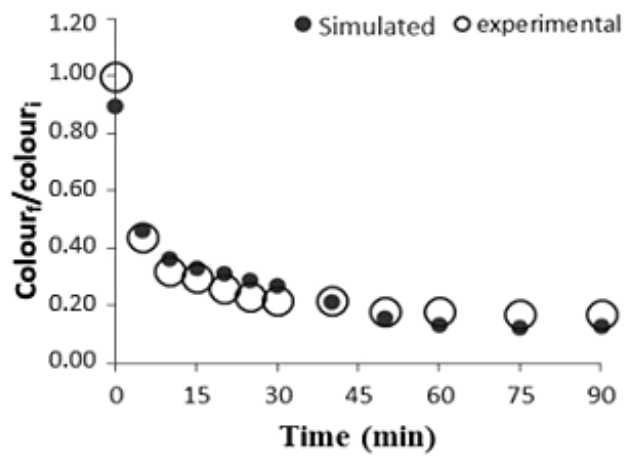

Treatment 12

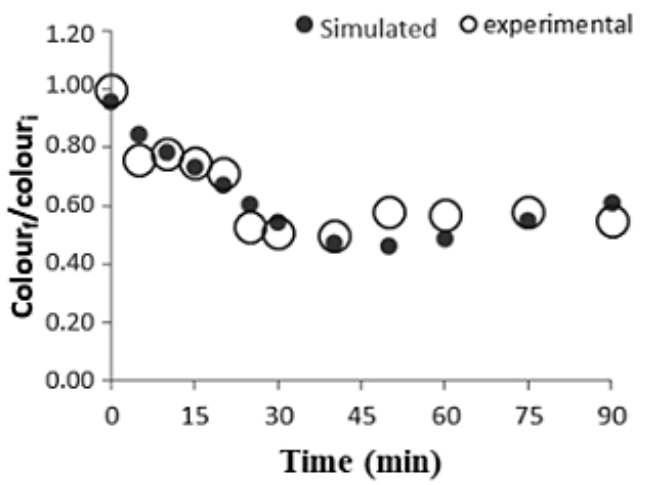

Treatment 14

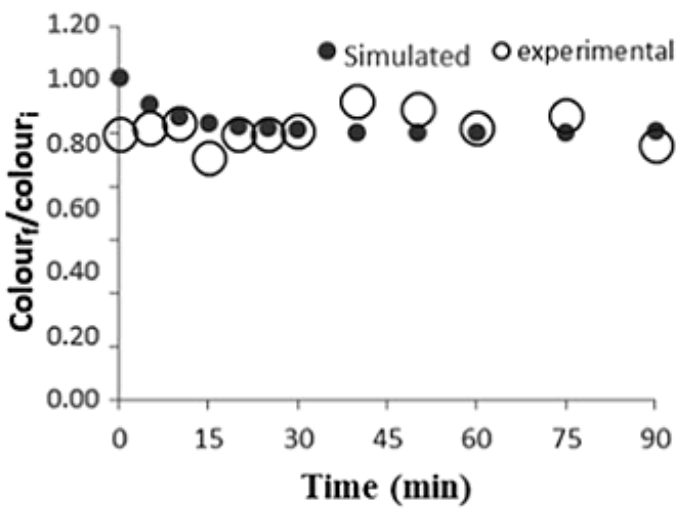

Treatment 11

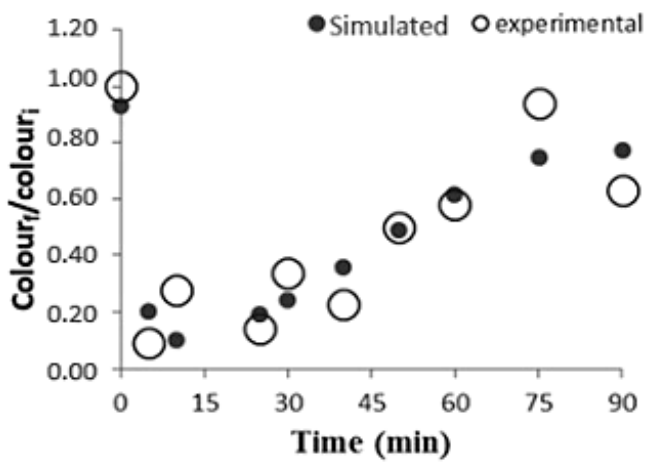

Treatment 13

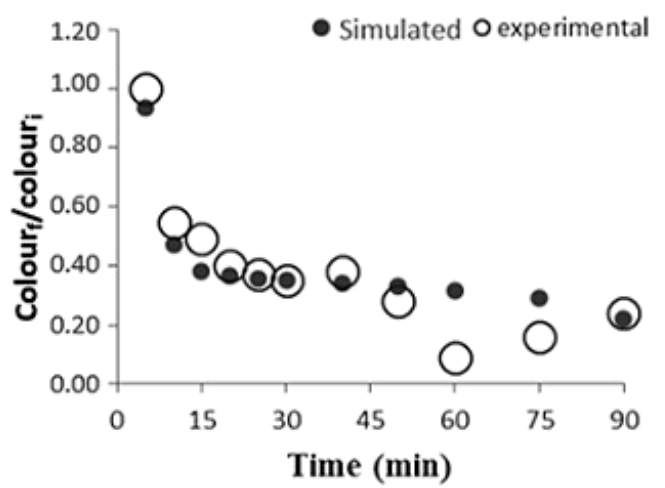

Treatment 15

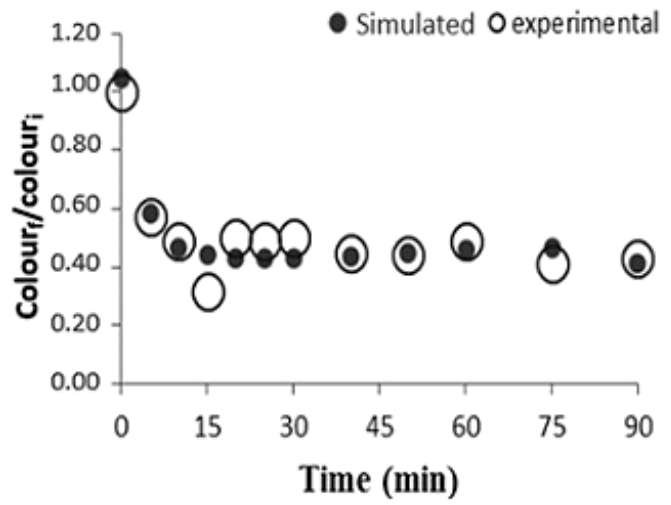

Figure 2. Profiles of the ICUMSA colour reduction treatments $\# 9\left(\mathrm{pH}=7.5 ; 50{ }^{\circ} \mathrm{C}\right.$ and $\left.500 \mathrm{mg}_{\mathrm{H} 2 \mathrm{O} 2} \mathrm{~L}^{-1}\right)$, \#11 $\left(\mathrm{pH}=11.68 ; 50{ }^{\circ} \mathrm{C}\right.$ and $\left.500 \mathrm{mg}_{\mathrm{H} 2 \mathrm{O} 2} \mathrm{~L}^{-1}\right), \# 12\left(\mathrm{pH}=7.5 ; 16.4^{\circ} \mathrm{C}\right.$ and $\left.500 \mathrm{mg}_{\mathrm{H} 2 \mathrm{O} 2} \mathrm{~L}^{-1}\right), \# 13\left(\mathrm{pH}=7.5 ; 83.6^{\circ} \mathrm{C}\right.$ and $\left.500 \mathrm{mg}_{\mathrm{H} 2 \mathrm{O} 2} \mathrm{~L}^{-1}\right), \# 14\left(\mathrm{pH}=7.5 ; 50{ }^{\circ} \mathrm{C} ; 0 \mathrm{mg}_{\mathrm{H} 2 \mathrm{O} 2} \mathrm{~L}^{-1}\right)$ and $\# 15\left(\mathrm{pH}=7.5,50{ }^{\circ} \mathrm{C}\right.$ and $\left.1.000 \mathrm{mg}_{\mathrm{H} 222} \mathrm{~L}^{-1}\right)$ in sugar syrup treated with $\mathrm{H}_{2} \mathrm{O}_{2}$ as compared to the values simulated by the ANN. 
The percentage of the mean square error of each variable for the reduction in ICUMSA colour (Figure 3), showed a higher significance degree for the initial Brix ( $42.63 \%$ of the total value) followed by temperature (21.19\%), $\mathrm{pH}(21.35 \%)$ and $\mathrm{H}_{2} \mathrm{O}_{2}$ (14.82\%). During the reaction time, there was a reduction in the Brix values, which was directly related to the reduction in the ICUMSA colour values. Sartori et al. (2017) reported that the reduction in the ICUMSA colour in sugarcane juice by $\mathrm{H}_{2} \mathrm{O}_{2}$ is associated with the precipitation of impurities from the sugarcane juice, such as proteins and phospholipids.

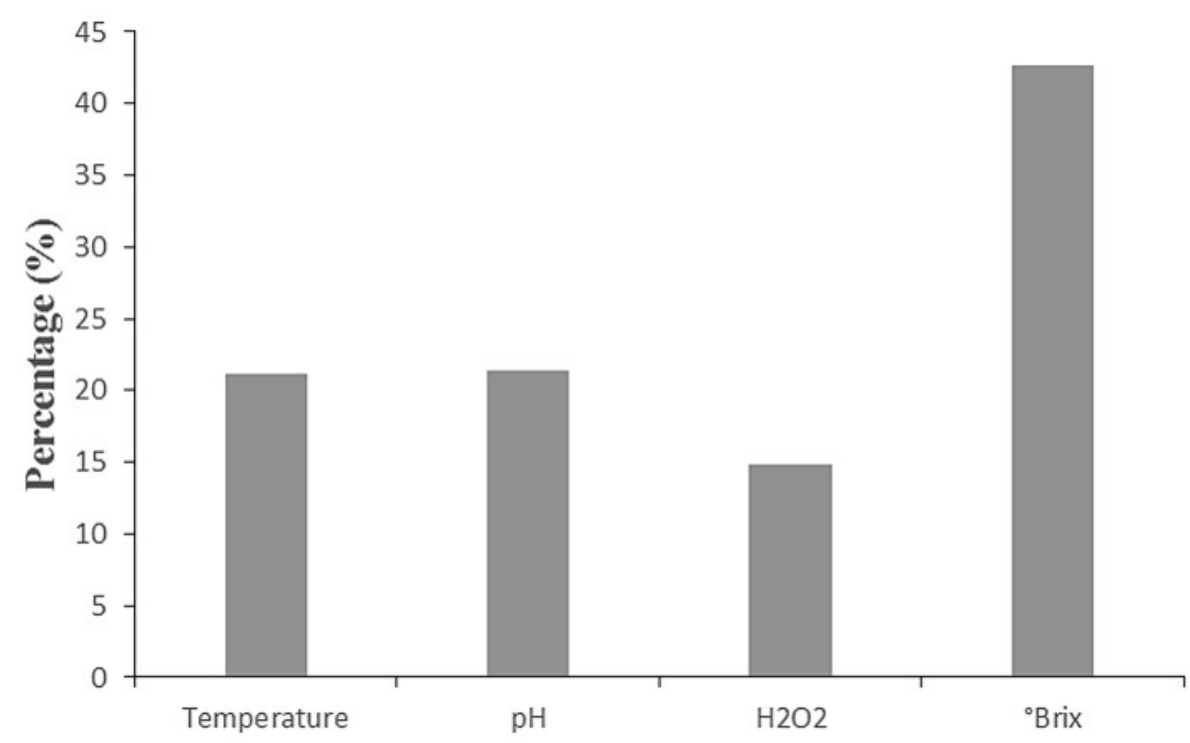

Figure 3. Relative importance of the neural network variables in the reduction of the ICUMSA colour.

Treatments \#7 $\left(\mathrm{pH}=5.0 ; 70{ }^{\circ} \mathrm{C}\right.$ and $\left.797.6 \mathrm{mg}_{\mathrm{H} 2 \mathrm{O} 2} \mathrm{~L}^{-1}\right), \# 8\left(\mathrm{pH}=10.0 ; 70{ }^{\circ} \mathrm{C}\right.$ and $\left.797.6 \mathrm{mg}_{\mathrm{H} 2 \mathrm{O} 2} \mathrm{~L}^{-1}\right)$, \#10 $\left(\mathrm{pH}=3.32 ; 50{ }^{\circ} \mathrm{C}\right.$ and $\left.500 \mathrm{mg}_{\mathrm{H} 2 \mathrm{O} 2} \mathrm{~L}^{-1}\right), \# 11\left(\mathrm{pH}=11.68 ; 50{ }^{\circ} \mathrm{C}\right.$ and $\left.500 \mathrm{mg}_{\mathrm{H} 2 \mathrm{O} 2} \mathrm{~L}^{-1}\right), \# 13(\mathrm{pH}=7.5$ and $83.6{ }^{\circ} \mathrm{C}$ and $\left.500 \mathrm{mg}_{\mathrm{H} 2 \mathrm{O} 2} \mathrm{~L}^{-1}\right)$ and $\# 15\left(\mathrm{pH}=7.5 ; 50^{\circ} \mathrm{C}\right.$ and $\left.1.000 \mathrm{mg}_{\mathrm{H} 2 \mathrm{O} 2} \mathrm{~L}^{-1}\right)$ presented sucrose degradation of around 55\% (Figure 4). At extreme pH values (acidic or basic) and high temperatures, sucrose is hydrolysed to glucose and fructose (Amani et al., 2017). Treatments \#10, \#11 and \#13 involved high temperatures and extreme $\mathrm{pH}$ values. According to Eggleston \& Vercellotti (2000), the rate of sucrose degradation can be influenced by the concentration of ions $\left(\mathrm{H}^{+}\right.$and $\left.{ }^{-} \mathrm{OH}\right)$, reaction temperature, presence of salts and the sucrose and monosaccharide concentrations. For Favero (2017), sucrose degradation occurs intensely at high temperatures and Mandro et al. (2017) found that at temperatures above $30^{\circ} \mathrm{C}$, sucrose was more severely degraded by hydrogen peroxide.

The constant speed for each sugar syrup treatment required to cause sucrose degradation was calculated in 15 min reactions of sugar syrup with $\mathrm{H}_{2} \mathrm{O}_{2}$.

Treatment $\# 10\left(\mathrm{pH}=3.32 ; 50{ }^{\circ} \mathrm{C}\right.$ and $\left.500 \mathrm{mg}_{\mathrm{H} 2 \mathrm{O} 2} \mathrm{~L}^{-1}\right)$ presented the highest rate of sucrose degradation (Figure 4). On the other hand, treatment $\# 4\left(\mathrm{pH}=10.0 ; 70{ }^{\circ} \mathrm{C}\right.$ and $\left.202.4 \mathrm{mg}_{\mathrm{H} 2 \mathrm{O} 2} \mathrm{~L}^{-1}\right)$ presented the lowest degradation rate, although the $\mathrm{pH}$ of 10.0 and temperature of $70^{\circ} \mathrm{C}$ represent conditions that are normally unfavourable for the stability of the sucrose structure. 

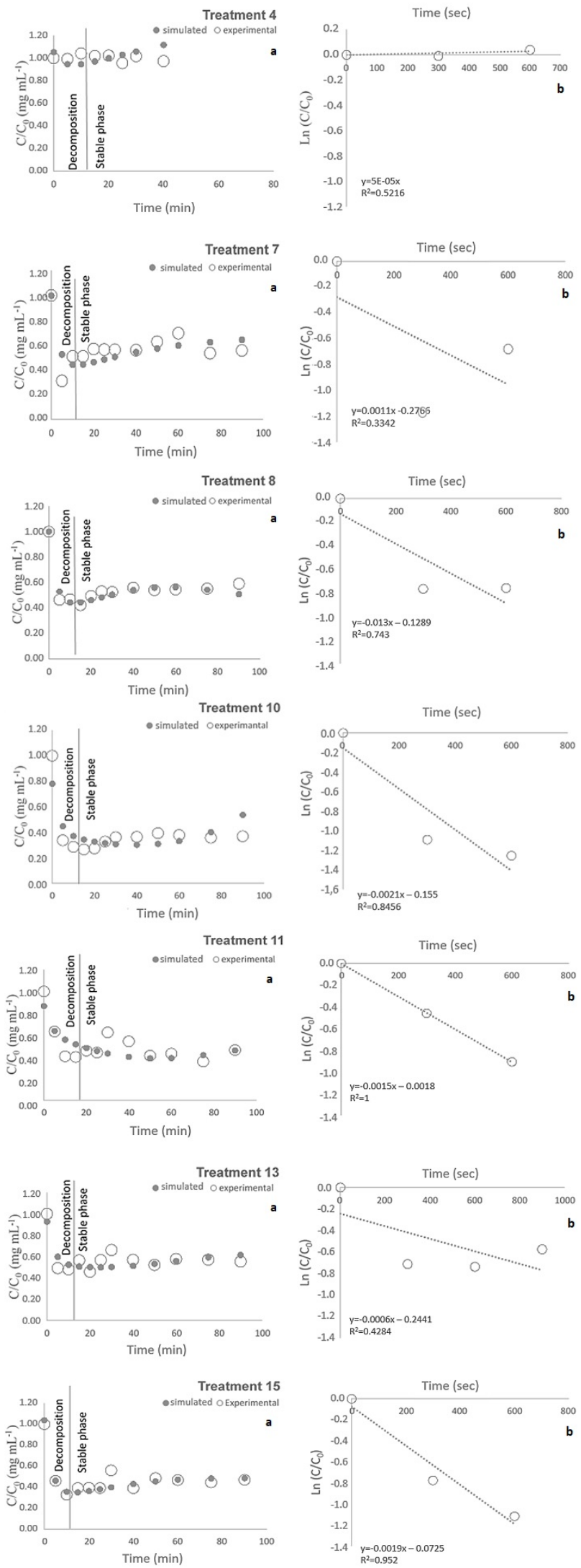

Figure 4. a) Profiles of sucrose degradation in treatments $\# 7\left(\mathrm{pH}=5.0 ; 70{ }^{\circ} \mathrm{C}\right.$ and $\left.797.6 \mathrm{mg}_{\mathrm{H} 2 \mathrm{O} 2} \mathrm{~L}^{-1}\right), \# 8(\mathrm{pH}=10.0$; $70{ }^{\circ} \mathrm{C}$ and $\left.797.6 \mathrm{mg}_{\mathrm{H} 2 \mathrm{O} 2} \mathrm{~L}^{-1}\right)$, \#10 $\left(\mathrm{pH}=3.32 ; 50{ }^{\circ} \mathrm{C}\right.$ and $\left.500 \mathrm{mg}_{\mathrm{H} 2 \mathrm{O} 2} \mathrm{~L}^{-1}\right), \# 11\left(\mathrm{pH}=11.68 ; 50{ }^{\circ} \mathrm{C}\right.$ and $\left.500 \mathrm{mg}_{\mathrm{H} 2 \mathrm{O} 2} \mathrm{~L}^{-1}\right)$, $\# 13\left(\mathrm{pH}=7.5 ; 83.6{ }^{\circ} \mathrm{C}\right.$ and $\left.500 \mathrm{mg}_{\mathrm{H} 2 \mathrm{O} 2} \mathrm{~L}^{-1}\right)$ and $\# 15\left(\mathrm{pH}=7.5\right.$ and $50{ }^{\circ} \mathrm{C}$ and $\left.1.000 \mathrm{mg}_{\mathrm{H} 2 \mathrm{O} 2} \mathrm{~L}^{-1}\right)$ in sugar syrup, 
according to the values simulated by the ANN. b) Kinetics of sucrose degradation reactions in $\mathrm{H}_{2} \mathrm{O}_{2}$ treatments, highlighting the phase with greater decomposition.

Of the treatments, $\# 9$ (Figure 5) presented the best colour $\times$ sucrose relationship, because it showed greater colour reduction (about $82 \%$ ) with lower sucrose degradation (about 33\%). In all the treatments analysed, the results were similar when comparing the theoretical and experimental values, and the best fits were observed for treatments $\# 8\left(\mathrm{pH}=10.0 ; 70{ }^{\circ} \mathrm{C}\right.$ and $\left.797.6 \mathrm{mg}_{\mathrm{H} 2 \mathrm{O} 2} \mathrm{~L}^{-1}\right)$ and $\# 9\left(\mathrm{pH}=7.5 ; 50{ }^{\circ} \mathrm{C}\right.$ and $\left.500 \mathrm{mg}_{\mathrm{H} 2 \mathrm{O} 2} \mathrm{~L}^{-1}\right)$.
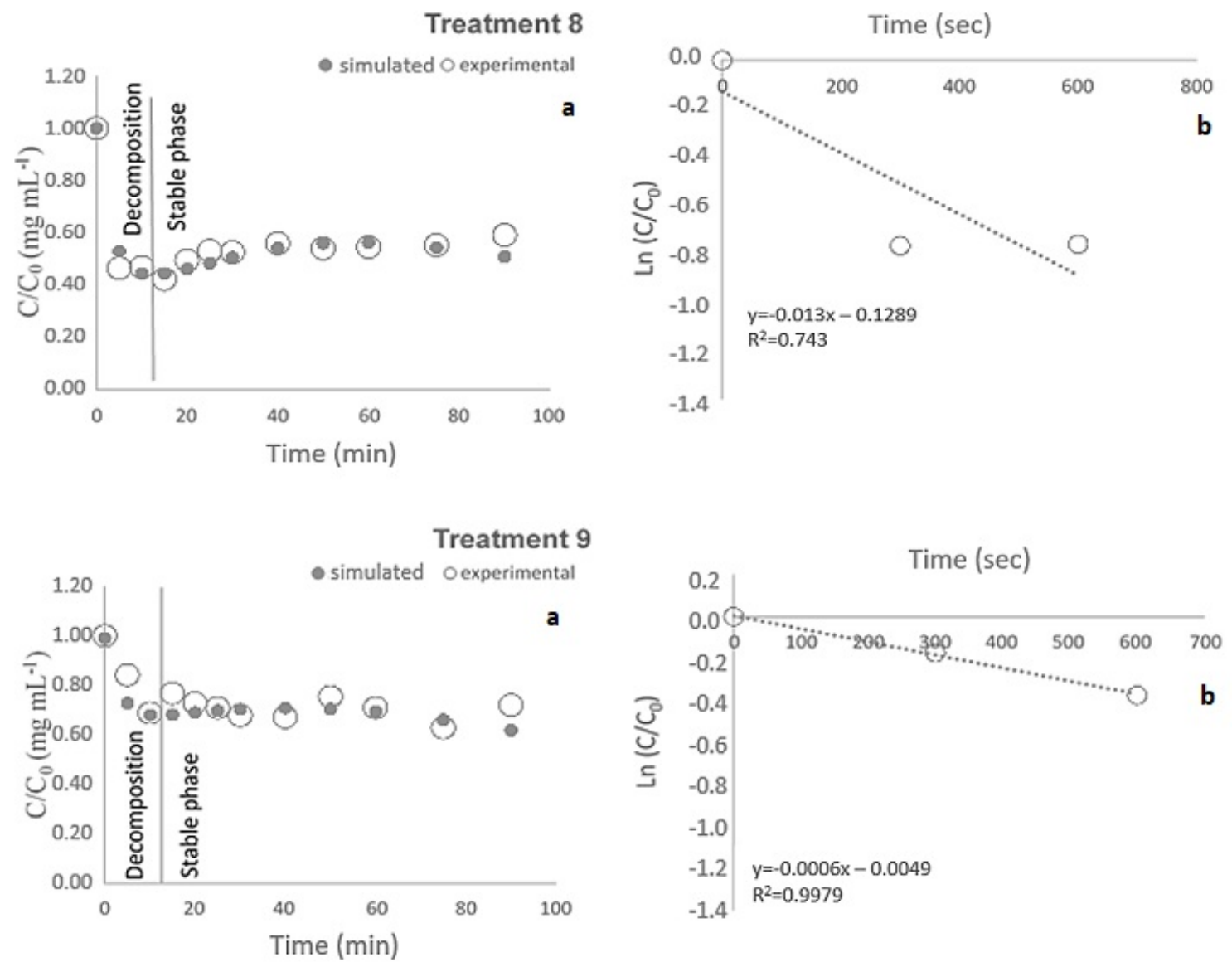

Figure 5. a) Profiles of sucrose degradation in treatments $\# 8\left(\mathrm{pH}=10.0 ; 70{ }^{\circ} \mathrm{C}\right.$ and $\left.797.6 \mathrm{mg}_{\mathrm{H} 2 \mathrm{O} 2} \mathrm{~L}^{-1}\right)$ and $\# 9$ $\left(\mathrm{pH}=7.5 ; 50{ }^{\circ} \mathrm{C}\right.$ and $500 \mathrm{mg}_{\mathrm{H} 2 \mathrm{O} 2} \mathrm{~L}^{-1}$ ) in sugar syrup according to values simulated by the ANN. b) Kinetics of the sucrose degradation reactions in the $\mathrm{H}_{2} \mathrm{O}_{2}$ treatments, highlighting the phase with greater decomposition.

The calculation of the relative importance of the variables showed that the factor with the greatest effect on sucrose degradation was the initial Brix, with a percentage of 54.38\% (Figure 6). For Sartori et al. (2017), in studies with sugarcane juice, sucrose was the most abundant soluble component in sugarcane juice and thus, any changes in Brix values affect the sucrose concentration. Hydrogen peroxide represented $17.50 \%$ followed by $\mathrm{pH}$ with $15.31 \%$ and temperature with $12.79 \%$. 


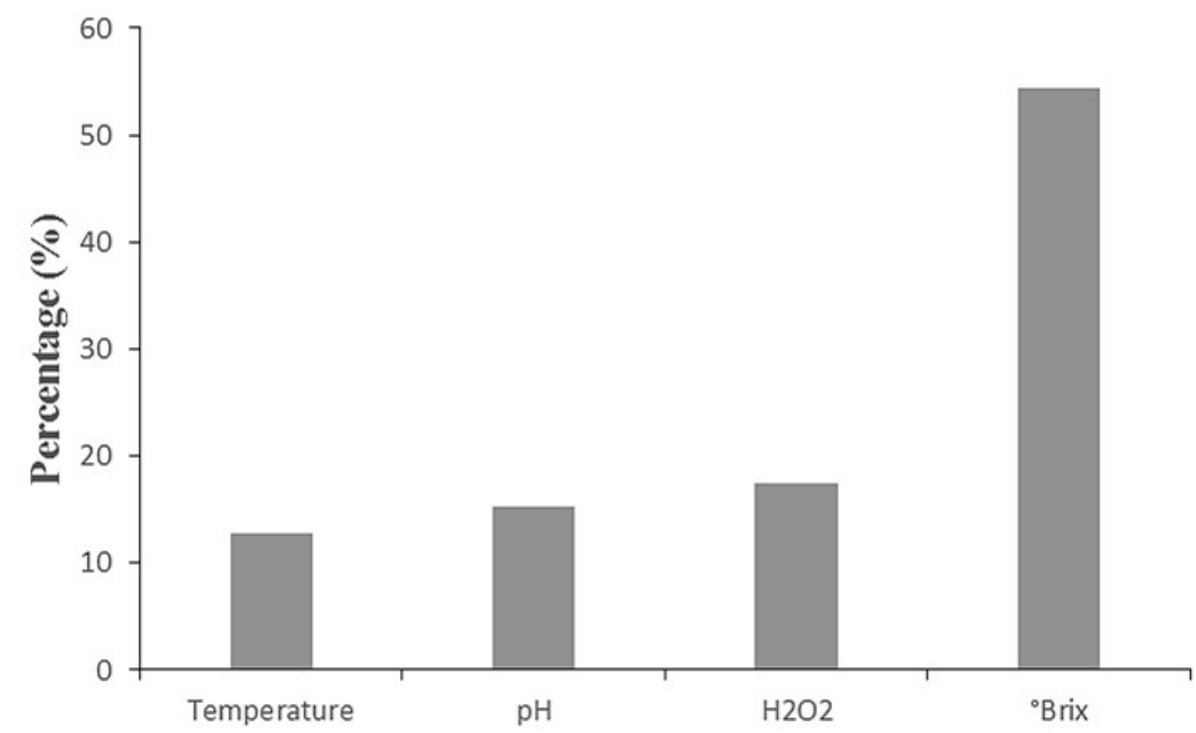

Figure 6. Importance of the neural network variables in the degradation of sucrose.

\section{Conclusion}

In all cases an ICUMSA colour reduction occurred in the sugar syrup after treatment; however, it was more pronounced under conditions of $\mathrm{pH}=7.5 ; 50{ }^{\circ} \mathrm{C}$ and $500 \mathrm{mg}_{\mathrm{H} 2 \mathrm{O} 2} \mathrm{~L}^{-1}$. The initial Brix was indicated as the variable with the greatest influence on ICUMSA colour reduction and sucrose degradation. The profile of sucrose degradation up to $90 \mathrm{~min}$ showed that the first $15 \mathrm{~min}$ were the most critical for degradation. The models presented a good fit, with the simulated values very close to the experimental values.

\section{Acknowledgements}

This work was supported by the São Paulo Research Foundation (FAPESP) [grants \#2009/54635-1 and \#2014/03292-5], the National Council for Scientific and Technological Development (CNPQ) [grant \# 310367/2013-1]. The authors are grateful to Prof. Dr. Antoniou Carlos Silva Costa Teixeira of the Polytechnic School of USP for supplying the software for the neural networks.

\section{References}

Amani, M., Barzegar, A., \& Mazani, M. (2017). Osmolytic effect of sucrose on thermal denaturation of pea seedling copper amine oxidase. The Protein Journal, 36(2), 147-153. PMid:28315108. http://dx.doi.org/10.1007/s10930-017-9706-1

Araujo, F. V. F., Yokoyama, L., \& Teixeira, L. A. C. (2006). Color removal in reactive dye solutions by UV/H2O2 oxidation. Quimica Nova, 29(1), 11-14. http://dx.doi.org/10.1590/S0100-40422006000100003

Baccar, R., Bouzid, J., Feki, M., \& Montiel, A. (2009). Preparation of activated carbon from Tunisian olive-waste cakes and its application for adsorption of heavy metal ions. Journal of Hazardous Materials, 162(2-3), 1522-1529. PMid:18653277. http://dx.doi.org/10.1016/j.jhazmat.2008.06.041

Crema, L. C. (2012). Clarificação por flotação com ar dissolvido (FAD) da calda de açúcar cristal para produção de açúcar refinado (Dissertação de mestrado). Universidade Estadual Paulista, São José do Rio Preto.

Eggleston, G., \& Vercellotti, J. R. (2000). Degradation of sucrose, glucose and fructose in concentrated aqueous solutions under constant $\mathrm{pH}$ conditions at elevated temperature. Journal of Carbohydrate Chemistry, 19(9), 1305-1318. http://dx.doi.org/10.1080/07328300008544153

Fairbanks, M. (2009). Celulose garante expansão da oferta de peróxido de hidrogênio. São Paulo: Química e Derivados. Retrieved in 2015, November 12, from http://www.quimica.com.br/pquimica/9958/h2o2-celulose-garante-expansao-da-ofertade-peroxido-de-hidrogenio-enquanto-despontam-novos-usos/Nov

Favero, D. M. (2017). Clarificação do caldo de cana-de-açúcar pelo processo de carbonatação (Dissertação de mestrado) Universidade Federal do Paraná, Curitiba.

Food and Drug Administration - FDA. (2015). Generally recognized as safe (GRAS). Silver Spring: U.S. Food and Drug Administration. Retrieved in 2015, August 05, from: https://www.fda.gov/Food/IngredientsPackagingLabeling/GRAS/ 
Guo, S., Huang, R., \& Chen, H. (2017). Application of water-assisted ultraviolet light in combination of chlorine and hydrogen peroxide to inactivate Salmonella on fresh produce. International Journal of Food Microbiology, 257, 101-109. PMid:28651076. http://dx.doi.org/10.1016/j.ijfoodmicro.2017.06.017

International Commission for Uniform Methods of Sugar Analysis - ICUMSA. (2011). Determination of the solution colour of raw sugar, brown sugar and coloured syrups at pH 7.0 (Method GS 1/3-7 - Raw Sugar). Berlin: ICUMSA.

Jervis, M. G., Smith, T. J., \& Drake, M. A. (2015). Short communication: the influence of solids concentration and bleaching agent on bleaching efficacy and flavor of sweet whey powder. Journal of Dairy Science, 98(4), 2294-2302. PMid:25660741. http://dx.doi.org/10.3168/jds.2014-8804

Kemp, S. L., Zaradic, P., \& Hansen, F. (2007). An approach for deter-mining relative input parameter importance and significance inartificial neural networks. Ecological Modelling, 204(3-4), 326-334.

http://dx.doi.org/10.1016/j.ecolmodel.2007.01.009

Lange, L. C., Alves, J. F., Amaral, M. C. S., \& Melo-Júnior, W. R. (2006). Tratamento de lixiviado de aterro sanitário por processo oxidativo avançado empregando reagente de Fenton. Engenharia Sanitaria e Ambiental, 11(2), 175-183. http://dx.doi.org/10.1590/S1413-41522006000200011

Mandro, J. L., Braga, N. L. L., Catelan, M. G., Baptista, A. S., Sartori, J. A. S., Correa, N. T., Rocha, A. L. B., Lima, R. B., \& Aguiar, C. L. (2015). Degradação de rutina em sistemas-modelo de caldo de cana-de-açúcar pela ação de peróxido de hidrogênio. Revista de Química Industrial, 747(5), 28-33.

Mandro, J. L., Magri, N. T. C., Sartori, J. A. S., \& Aguiar, C. L. (2017). ICUMSA colour reduction in concentrated raw sugar solutions by an oxidative process with hydrogen peroxide. Brazilian Journal of Food Technology, 20(8), 1-8.

Mane, J. D., Jambhale, D. B., Yewale, A. V., \& Phadnis, S. P. (2000). Mill scale evaluation of hydrogen peroxide as a processing aid: Improvement in the quality of plantation white sugar. International Sugar Journal, 102(1222), 530-553.

Mattos, I. L., Shiraishi, K. A., Braz, A. D., \& Fernandes, J. R. (2013). Peróxido de hidrogênio: Importância e determinação. Quimica Nova, 26(3), 373-380. http://dx.doi.org/10.1590/S0100-40422003000300015

Nascimento, C. A. O., Giudici, R., \& Guardani, R. (2000). Neural network based approach for optimization of industrial chemical processes. Computers \& Chemical Engineering, 24(9-10), 2303-2314. http://dx.doi.org/10.1016/S0098-1354(00)00587-1

Rodrigues, M. V. N. (1998). Otimização da produção de xarope de açúcar invertido através do uso de resinas de troca-iônica (Dissertação de mestrado). Universidade Estadual de Campinas, Campinas.

Russo, D., Siciliano, A., Guida, M., Galdiero, E., Amoresano, A., Andreozzi, R., Reis, N. M., Li Puma, G., \& Marotta, R. (2017). Photodegradation and ecotoxicology of acyclovir in water under $\mathrm{UV}_{254}$ and $\mathrm{UV}_{254} / \mathrm{H}_{2} \mathrm{O}_{2}$ processes. Water Research, 122, 591602. PMid:28628881. http://dx.doi.org/10.1016/j.watres.2017.06.020

Sartori, J. A. S., Correa, N. T. C., \& Aguiar, C. L. (2015a). Clarification of sugarcane juice by hydrogen peroxide: effects of the presence of dextran. Brazilian Journal of Food Technology, 18(4), 299-306. http://dx.doi.org/10.1590/1981-6723.4215

Sartori, J. A. S., Galaverna, R., Eberlin, M. N., Correa, N. T., Mandro, J. L., \& de Aguiar, C. L. (2015b). Elucidation of color reduction involving precipitation of non-sugars in sugarcane (saccharum sp.) juice by fourier-transform ion cyclotron resonance mass spectrometry. Journal of Food Processing and Preservation, 39(6), 1826-1831. http://dx.doi.org/10.1111/jfpp.12417

Sartori, J. A. S., Ribeiro, K., Teixeira, A. C. S. C., Magri, N. T. C., Mandro, J. L., \& Aguiar, C. L. (2017). Sugarcane juice clarification by hydrogen peroxide: predictions with artificial neural networks. International Journal of Food Engineering, 13(2), 18. http://dx.doi.org/10.1515/ijfe-2016-0199

Spasiano, D., Russo, D., Vaccaro, M., Siciliano, A., Marotta, R., Guida, M., Reis, N. M., Li Puma, G., \& Andreozzi, R. (2016). Removal of benzoylecgonine from water matrices through $\mathrm{UV} 254 / \mathrm{H}_{2} \mathrm{O}_{2}$ process: Reaction kinetic modeling, ecotoxicity and genotoxicity assessment. Journal of Hazardous Materials, 318, 515-525. PMid:27450344. http://dx.doi.org/10.1016/j.jhazmat.2016.07.034

Stout, M. A., Park, C. W., \& Drake, M. A. (2017). The effect of bleaching agents on the degradation of vitamins and carotenoids in spray-dried whey protein concentrate. Journal of Dairy Science, 100(10), 7922-7932. PMid:28780108. http://dx.doi.org/10.3168/jds.2017-12929

Teran, F. (2014). Aplicação de fotocatálise heterogênea e homogênea para a remoção de cor em efluentes provenientes de indústria de procesamento de couro. Revista Monografias Ambientais, 13(3), 3316-3325.

http://dx.doi.org/10.5902/2236130813232

Üzer, A., Durmazel, S., Erçag, E., \& Apak, R. (2017). Determination of hydrogen peroxide and triacetone triperoxide (TATP) with a silver nanoparticles—based turn-on colorimetric sensor. Sensors and Actuators. B, Chemical, 247, 98-107.

http://dx.doi.org/10.1016/j.snb.2017.03.012

Funding: São Paulo Research Foundation (FAPESP) [grants \#2009/54635-1 and \#2014/03292-5]. National Council for Scientific and Technological Development (CNPQ) [grant \#310367/2013-1] 